\title{
CULTURE AND INTELLECTUAL PROPERTY DEVELOPMENT IN INDONESIA
}

\author{
Agus Sardjono ${ }^{1}$
}

\begin{abstract}
The conception of Intellectual Property Right (IPR) is generally misunderstood by among common people. In order to obtain a more comprehensive understanding of $I P R$, we may as well start with the most dominant point of view, namely that from the perspective of the State and Government. This point of view is dominant because the State and Government are the institutions which havethe authority to make law, to implement law and to interpret the law in the various forms of itsimplementation.

A study of IPR can be taken from wider view, as cultural perspectivetake the approach of looking at various events related to the implementation of the laws concerned. It also provide various situations to analyze related to the implementation of Copyright Law in various regions all over Indonesia.

Within current situation, after Indonesia has ratified the WTO/TRIPs, the consequence now is binding, politically, legally and economically, although we may freely provide the needs of our people, in this case : IPR protection system.

There are of course many other things in the spirit of the Constitution and the Indonesian nation that can be explored further and applied in the IPR protection system. In the end, IPR as the part of the culture can be developed further by taking into consideration and looking into possibility that much suitable to the needs of Indonesian respective communities.
\end{abstract}

Keywords: copyright law, culture, intellectual property

\section{Introduction}

Viewed from many different perspectives, there are some interesting points that emerge relatedto IPR. There is a generally prevailing view among common people that IPR is an abstract,altogether strange concept. This is indicated, among other things, in the frequently incorrect use of the word 'patent'. For instance, people are often heard saying as follows: "obatnya paten banget lho! ...."2, or "tutupnya sudah paten! gak bisa dibuka..."3, or "apakah mereknya sudah dipatenkan?..." ${ }^{5}$

\footnotetext{
${ }^{1}$ Based on the researches made by the writer as part of teamwork in : (1) Preliminary Review of LegislaProfessor of Law, Faculty of Law University of Indonesia.

${ }^{2}$ In free translation into English, it reads as follows: "this medicine really works".

${ }^{3}$ In free translation into English, it reads as follows: "the seal is set, it cannot be removed".

${ }^{4}$ In free translation into English, it reads as follows: "has this mark been patented?".

${ }^{5}$ Such expressions can be frequently heard in conversations among community members on many different occasions.
} 
When asked the question, what is IPR, people would in general respond by asking back,what is IPR? All of the foregoing indicates that IPR is a foreign concept to the people at large, aconcept they do not seem to understand. Moreover, even certain law scholars may be unfamiliar with IPR, as IPR subjects are not included in the curriculum of all law faculties.

On the other hand, seen from the Government's point of view, particularly the institutions in charge of drafting laws and regulations or the bureaucracy in charge of administering theimplementation of the mandates given under law, IPR is perceived as a single and functional concept. IPR is simply related to the provisions of the law and implementing regulations. In the view of bureaucratic circles, IPR is all about patents, marks, copyright, and the like, which must be implemented in the territory of the Republic of Indonesia because they are provided for under the law.

From the perspective of culture, ${ }^{6}$ IPR can be seen from many different aspects, with results that highly differ depending on the person observing them. To business actors, IPR is a tool to achieve various objectives, all of which are aimed at achieving the highest possible profits. To the industries relying on technological advantages, IPR is patent which has the function of maintaining exclusivity in the application of technology developed in the company concerned. To entrepreneurs trading in goods, IPR is trade mark which has the function of differentiating the goods or services they are trading in. To the music and film industry, IPR is copyright which has the function of a tool to monopolize the reproduction and distribution of music and film that they are dealing with. To the world of education, IPR is an object of study and research in the context of developing science and technology. Academicians can view IPR from many different perspectives, ranging from philosophy, law, history, economics, and the like, using various theoretical as well as empirical approaches and viewpoints.

Essentially, viewed from the perspective of culture, IPR appears to be a highly embellished and colorful concept. That may be one of the reasons why the implementation of IPR protection in a plural society with diverse interests such as Indonesia invites debate and heated discussion so frequently. Given such circumstances, it would be naive for anyone to hold on to their own perceptions on IPR without taking into account the existence of other views which are based on subjectivity.

Speaking of IPR development, either from the legal, technological or from the economic aspect, IPR cannot be viewed from one single perspective. And this is exactly where the main issue arises. It is often difficult for sectors that are dealing with IPR to take an inclusive standpoint. For instance, in the drafting process, law makers frequently tend to disregard various related aspects, including the impact of the implementation of a particular regulation. Drafting laws and regulations is merely viewed as implementation of Tupoksi (Principal Tasks and Functions) of the respective sectors or task areas, hence their implementation is limited to the achievement of their respective Tupoksi objectives.

\footnotetext{
${ }^{6}$ In this paper, culture is not only used in the sense of arts and various forms of arts; rather than that, culture includes a broader understanding as stated by Kuntjaraningrat in his various articles. See Kuntjaraningrat, PengantarAntropologi, (An Introduction to Anthropology), (Jakarta: AksaraBaru, Cet.V, no year indicated).
} 
It is in such context that the cultural study of IPR development becomes significant, both from the economic as well as from the technological point of view. IPR should not be taken out of its context, namely the society in which culture lives and develops.

\section{Understanding various different points of view}

In order to obtain a more comprehensive understanding of IPR, we may as well start withthe most dominant point of view, namely that from the perspective of the State and Government.This point of view is dominant because the State and Government are the institutions which have the authority to make law, to implement law and to interpret the law in the various forms of its implementation. Due to the Government's dominant view, there is a tendency on part of its apparatus to monopolize truth itself.

The Indonesian Government appears to take the view that IPR laws and regulations are needed in order to adjust to the trends in global trade. In the current global era, developing countries such as Indonesia do not have a choice but to accommodate the interests of industrialized countries which have extended substantial aid to developing countries.

In the context of economic development, for instance, developing countries have become highly dependent on the in-flow of foreign capital. Foreign investment brings in not only capital to the host country; it also brings in technology which is indeed highly needed by developing countries. Developing countries that refuse to accommodate the demands of developed countries are likely to become isolated in the global market. This is even more likely to occur in the case of developing countries which do not have a strong bargaining position. ${ }^{7}$

Indonesia's weak bargaining position has been due to its economic dependency on donor countries. This has created an opportunity for certain forces which played a part in influencingthe process of formulating Indonesia's IPR laws. This was manifested, among other things, in the formation of Tim Keppres $34 .^{8}$ The tasks of this Team included the following, among other things: drafting IPR laws such as Law No. 7 Year 1987 to amend Law No. 6 Year 1982 concerning Copyright, Law No. 6 Year 1989 Concerning Paten, Law No. 19 Year 1992 concerning Mark. All of the above mentioned three laws were subsequently amended by Law No. 12, 13, and 14 Year 1997 respectively. Continuous improvements were made during the mandate of this Tim Keppres $34^{9}$.

Up to the present time, several new IPR laws have been formulated and adopted in Indonesia, including the following, among other things: Law

${ }^{7}$ An analysis of the dependency of developing countries on developed countries can be conducted based on the dependency theory. See Suwarsono \& Alvin Y. So, Social Change and Development, (Jakarta: LP3ES, 1994)

${ }^{8}$ It is referred to as Tim Keppres 34 because this team was formed based on Presidential Decree No. 34 Year 1986 dated July 30, 1986.

${ }^{9}$ Tim Keppres 34 was dissolved on October 29, 1998 by virtue of Presidential Decree Number 189 Year 1998 concerning the Revocation of Presidential Decree Number 34 Year 1986. 
No. 30 Year 2000 concerning Trade Secret, Law No. 31 Year 2000 concerning Industrial Design, Law No. 32 concerning Integrated Circuits, Law No. 14 Year 2001 concerning Paten, Law No. 15 Year 2001 concerning Mark, and Law No. 19 Year 2002 concerning Copyright. All of the aforementioned laws have been the result of endeavors to meet the requirements as a result of the ratification of WTO/TRIPs in 1994 based on Law No. 7 Year 1994.

In formulating the above mentioned IPR laws, Tim Keppres 34 most certainly did not use the system of values or norms rooted in the Indonesian community itself, as the Indonesia society in general is not familiar with, and does not understand a regime which is individualistic and capitalistic in nature such as the IPR regime. The Indonesian society has communal and spiritual characteristics, which stand in stark contrast with the basic philosophy of the IPR regime. ${ }^{10}$ It is therefore relatively easy to conclude that the references used in the formulation of IPR laws in Indonesia can be traced back to international conventions such as the Paris Convention, the Berne Convention, and others. It has been for the same reason that the IPR regime remains a foreign regime to the most part of the Indonesian society. Moreover, there are many law scholars in Indonesia who may be unfamiliar with the IPR regime itself.

In the Government's perspective, the formulation of IPR laws is the implementation of a task mandated under the Law Ratifying the WTO/TRIPs [Law No. 7 Year 1994]. It goes without saying that the substance of IPR laws in Indonesia need to be adjusted to the norms spelled out in the above mentioned international conventions. Consequently, it can also be stated that the formulation and adoption of IPR laws in Indonesia has been the result of transplanting foreign law in to the national legal system. As is the case with human organ transplantation, if the transplanted organ is suitable to the body receiving it, the transplantation process can be expected to have a healing effect. On the other hand, if the transplanted organ is not suitable to the body receiving it, the transplantation process can have a fatal effect on the patient. There are similar implications in the case of transplanting IPR laws into the Indonesian legal system. If the foreign law concerned is suitable to the legal system applied in Indonesia, and if it can be expected to meet most of the needs of the Indonesian people, the transplantation of the law is likely to benefit the Indonesian nation. On the other hand, if the foreign law is not suitable, the transplantation process can damage the Indonesian legal system as a whole.

In reality, there has been no significant empirical evidence available to date proving that IPR laws have been able to bring a positive impact on the economic growth of developing countries, including Indonesia. ${ }^{11}$ On the contrary, there has been an actual flow of financial resources from developing countries to developed countries in the form of royalties. ${ }^{12}$ Frederick Abbott goes even

\footnotetext{
${ }^{10}$ For further reading on this antinomy, please refer to Agus Sardjono, Hak Kekayaan Intelektual dan Pengetahuan Tradisional, (Intellectual Property Rights and Traditional Knowledge) (Bandung: Alumni, 2010).

${ }^{11}$ Frederick Abbott, et al. The International Intellectual Property System: Commentary and Materials, Part One. (Kluwer Law International, 1999), p. 8.

${ }^{12}$ Suwarsono, Perubahan Sosial dan Pembangunan, (Social Change and Development) 99. It is interesting to note an interview that was broadcast by Radio 97.05 FM Jakarta with Dita Indah Sari On
} 
further by stating that IPR protection is harmful to developing countries. ${ }^{13}$ The question is why has Indonesia continued to apply IPR laws, while there is evidence that the application of such laws has not been able to bring benefit to most of the Indonesian people? The simple answer to that question may be that Indonesia needs to adjust to international agreements in order to be accepted as a member of the global community. By doing so, Indonesia will avoid being isolated in global trade, which will bring, in its turn, benefit to the Indonesian nation as a whole. That is what Indonesia needs right now.

Such view of the Government is fully supported by business circles, particularly those successfully using the IPR regime for their businesses. The IPR system has helped them monopolize technology in the commercial area through the protection system set forth in the provisions of laws and regulations.

Business circles, particularly those based on specific technology, are highly in favor of the TRIPs (Trade-related aspect of intellectual property rights) provisions. The Government, in this case the drafters of laws, are bound by the ratification of the WTO/TRIPs requiring the adoption of these provisions in Indonesia's legal system. The TRIPs contains specific provisions concerning, among other things, patentable subject matter, ${ }^{14}$ namely providing patent protection to invention in all fields of technology, including pharmaceutical paten $\mathrm{t}^{15}$ and even biotechnology. ${ }^{16}$ It is further asserted that patent is granted only to inventions that are new and contain inventive steps, and are industrially applicable.

The requirement of being industrially applicable is inseparable from the issue of capital. Patent will never exist if it cannot be applied in the industrial process. It becomes rather obvious, therefore, that the focus of protection is indeed not on individual creativity, but on monopolizing such individual creativity in an industrial activity. The owner of capital does not wish to lose

Thursday, February 7, 2002, between 8:00 and 8:30 a.m. The interview was conducted related to Dita's refusal to accept a US\$50,000.00 award from footwear industry Nike. In the interview, Dita compared the wages of laborers of Nike Indonesia to the royalty paid to the owner of the said trade mark. The wages of laborers amounted to only $0.4 \%$ of total sales, while the royalty payable totaled $33 \%$ of total sales. These figures clearly indicate a sharp contrast between the funds circulating in Indonesia in the form of wages and the funds flowing out of Indonesia in the form of royalties. Unfortunately, the author does not have data or documents that can support the authenticity of this news. However, assuming its authenticity, it supports the thesis that IPR are causing the outflow of financial resources from developing countries to developed countries. Despite the fact that the above mentioned data is relatively old (2002), in view of the current trends taking place in the area of patent applications in Indonesia, there is continued foreign dominance in the use of the IPR system to date.

${ }^{13}$ Frederick M. Abbott, "Protecting First World Assets in the Third World: Intellectual Property Negotiations in the GATT Multilateral Framework", Vanderbilt Journal of Transnational Law, (Vol. 22, No.4, 198), 691.

${ }^{14}$ Article 27 TRIPs Agreement.

15 Report of the AppelateBody of WTO in the dispute between the U.S. and India gives the recommendation that India should provide patent protection in the field of pharmaceuticals. See Frederick Abbott, et al, TheInternational Intellectual Property System: Commentary and Materials, (The Hague: Kluwer Law International, 1999), 533-534.

${ }^{16}$ The case of Diamond, Commissioner of Patents and Trademarks vs. Chakrabarty (Supreme Court of USA, 447 U.S.303) is an important example related to patent in the field of bio-technology. See Lihat Abbott, ibid., 29-40. 
theadvantage obtained from the use of his capital to produce an invention protected by patent.

Another proof that the patent regime provides protection only to the owner of capital is the fact that not all companies applying for patent are actually interested to implement such patent. For instance, a European company which applies for a patent in Indonesia may notnecessarily implement such patent by investing capital in Indonesia. The decision to actually implement a patent is usually subject to a cost-benefit analysis. As Ritchie notes, multinational pharmaceutical companies applying for a patent in a country do not always end up establishing aplant to implement the patent concerned. ${ }^{17}$ They only apply for patent protection in order to monopolize the pharmaceutical technology in the country concerned. By doing so, their mainconcern is business competition in the context of protecting the capital invested in conducting pharmaceutical research which resulted in the invention concerned.

This fact is yet another proof that the issue of transfer of technology affixed to the implementation of patent regime is nothing more than a mere slogan. Although the Indonesian patent law contains provisions requiring that every patent issued in Indonesia must be implemented in Indonesia ${ }^{18}$, in reality there is no control mechanism to ensure that such requirement is complied with by foreign patent owners. In other words, the idea of transfer of technology by applying the patent regime is only a lofty ideal articulated in the law. ${ }^{19}$ The actual issue behind the transfer of technology is the protection of the owner of capital. ${ }^{20}$

The above statement is further proved by the fact that more than $80 \%$ of patent rights issued in Third World countries are owned by foreign multinational companies. Out of these $80 \%$, more than $90 \%$ are patents that are not implemented by the said companies. ${ }^{21}$ In the context of patents in the pharmaceutical industry, this situation is obviously harmful to developing countries which need adequate and affordable medicine to be available. Blocking patent by multinational corporations (MNCs) has the effect of increasing prices of pharmaceutical products in developing countries, ${ }^{22}$ as developing countries have to import them at a price fully determined by the said MNCs.

${ }^{17}$ Mark Ritchie, et al, "Intellectual Property Rights and Biodiversity: The Industrialization of Natural Resources and Traditional Knowledge”, St Johns Journal of Legal Commentary, (Vol. 11, 1996).

${ }^{18}$ Article 17 paragraph (1) of Law No. 14 Year 2001 concerning Patent.

${ }^{19}$ Set forth in the Elucidation on Article 17 paragraph (1) of Law No. 14 Year 2001. This may the fact that Abbott is referring to as there being no evidence that the patent regime has had a significant impact on the transfer of technology or that it has contributed to the economic growth of developing countries. See Abbott, The International Intellectual Property System, 8.

${ }^{20}$ Meika Foster's remark indicates that gigantic global pharmaceutical companies are constantly behind the issue of the significance of the patent regime with the aim of protecting their research results, saying that: "withoutpatent protection much of the research currently available would not exist". See Meika Foster, "The Human Genome Diversity Project and the Patenting of Life: Indigenous People Cry Out", Canterbury Law Review, (Vol. 7, 1999), p. 358.

${ }^{21}$ Ritchie, et al., "Intellectual Property Rights and Biodiversity”, p. 439.

22 The issue of high prices of pharmaceutical products occurring as a result of patent protection for pharmaceutical products is also discussed in the article by Foster, "The Human Genome Diversity Project", 360- 361. 
The import of such highly priced pharmaceutical products also affects the trade balance between developed and developing countries. Financial resources in developing countries are absorbed by developed countries in the form of royalty payments to MNCs. At the same time, MNCs do not make any investments at all in developing countries. It is therefore rather interesting to note David Vaver's idea that patents should be granted to innovations that bring substantial benefit to the community of the country granting the patent concerned. ${ }^{23}$

If we look at the history of the TRIPs, ${ }^{24}$ whereby India and several other developing countries had been aspiring for a system which is different from the currently existing TRIPs system, one can assume that if India and other developing countries had prevailed in their aspirations during the Uruguay Round, developing countries, including Indonesia, would have been in a different situation than today. Indonesia is one of the member countries participating in the TRIPs agreement. The current issue for Indonesia related to IPR is adjusting its national laws to the international agreements related to IPR. Failing to making such adjustments would put Indonesia in a difficult position, as it would be subject to various international trade sanctions based on the WTO Agreement regime. ${ }^{25}$

Such functional view has been a dominant consideration, particularly among IPR legislative circles. Such functional view has also had considerable influence on most law scholars creating a tendency among them to study IPR from the normative aspect only. ${ }^{26}$ Scholars subscribing to legal formalism are necessarily of the view that the provisions of IPR laws drafted and enacted by an authorized legislative institution must be implemented in accordance with the prevailing law. This view is often contradictory to the view held by the sociological approach, which tends to be more inclined towards the law in action rather than the law in the book.

In the philosophical approach, IPR is viewed as an object of study analyzed by taking a certain distance. IPR is viewed as the outcome of a thinking process which is highly influenced by its supporters. For instance, to the followers of natural law, IPR is likely to be considered from the aspect of justice and specific norms created based on the natural law doctrine. For instance: those viewing IPR based on the perspective adopted by the followers of Thomas Aquinas will consider IPR as the materialization of the idea of goodness.

\footnotetext{
${ }^{23}$ David Vaver, "Intellectual Property Today: Of Myths and Paradoxes", Canadian Bar Review, (Vol. 69, 1990), p. 120-121.

${ }^{24}$ See Agus Sardjono, Membumikan HKI di Indonesia, (Materializing IPR in Indonesia) (Bandung: NuansaAulia, 2009), p. 2-5.

25 There are at least 3 sanctions that would be applicable if Indonesia failed to make the necessary adjustments to the WTO Agreement, namely: (1) amending its internal laws to make them compliant with the WTO Agreement, (2) paying compensation to the State winning in the panel proceedings, (3) imposition of trade sanctions. See articles 19 (1) and 22 Annex 2, Agreement Establishing The World Trade Organization 1994.

${ }^{26}$ In general, legal scholars with a tendency towards positivism are likely to fully support the implementation of IPR laws, without taking into account the relevant philosophical and cultural aspets. While this statement is not yet adequately supported quantitatively, several observations indicate that this view has been frequently expressed by legal scholars involved in the study of IPR.
} 
According to Aquinas, goodness and happiness as the ultimate goal of every human action are the moral basis of positive law. ${ }^{27}$ Accordingly, there is a very close relationship between moral law and positive law, and positive law must be in accordance with morality. Law must be in a position to enable human beings to develop according to their nature: by upholding human dignity, being just, ensuring equity and liberty, promoting public interest and welfare.

In Aquinas' view, law can contain injustice when it is contrary to the goal of human welfare. Injustice can occur under law in the following three instances. First, when the authorities in power impose a law that fails to ensure general welfare, and is enacted arbitrarily only to suit the needs of the authorities in power. Second, when legislators exceed their existing authorities. Third, when a law is imposed by force on the community, even when it is intended to serve the public good. Aquinas refers to the latter as an act of force by law.

In his Summa Theologiae, Aquinas defines law as an order of the conscious mind for public goodness and promulgation by the authorities that have the duty of leading the community. The characteristics of such law are described by Aquinas as follows, among other things: ${ }^{28}$

1. Rational, because law is an order of the conscious mind. In other words, a person who has a certain objective is commanded by his or her consciousness to act in a manner toachieve such objective.

2. Teleological, or objective-oriented, namely for the public good. In this view, law is made based on the society's best interests, namely to achieve public good.

3. In order for the above mentioned interest to materialize, legislation is the over all authority of the people, or a person/persons appointed to represent the interests of thepeople.

The relationship between natural law and positive law is usually formulated in terms ofrights. ${ }^{29}$ Right is granted to another person based on the principle of equity. A right is created intwo ways. First, by nature, which is referred to as fundamental right. Fundamental rights as provided for by natural law take their origin from God. Second, right based on agreement or contract with another person, either based on individual or public agreement. This type of right is referred to as positive right and it is provided for under positive law.

In the perspective of the followers of Thomas Aquinas, IPR is the right of a person which must be protected by law. The idea proposed by Aquinas seems to end right there, as he does not specify who that person is. Is it the creator, author, or discoverer in the field of technology? Is ita person who has funded someone else, and the latter has come up with something for the person having

${ }^{27}$ Thomas Aquinas, The Summa Theologica: On the Essence of Law, (edited with an introduction by Anton C. Pegis), (New York: The Modern Library, no year indicated), 609-613.

${ }^{28}$ Thomas Aquinas, Summa Theologica, in Lord Lloyd of Hampstead, Introduction to Jurisprudence, 3th ed., (Praeger Publisher, 1972), 96-97.

${ }^{29}$ Sumaryono, Etika Hukum: Relevansi Hukum Kodrat Thomas Aquinas, (Legal Ethics: The Relevance of Thomas Aquinas' Natural Law) (Yogyakarta: Kanisius, 2002), 21. 
financed the project? This is the point at which the concept of work for hire comes into existence.

The idea of positive rights (rights arising from agreement between individuals or public agreement - the drafters of State law) and the concept of work for hire were used by thinkers in the field of IPR law in creating norms that fulfill the needs. It was against such background that the discourse on the influence of interest in the law making process subsequently came to the surface. Leading philosophers to the view that IPR is a product of individualismcapitalism resulting from the influence in the process of IPR law making. Such influence was further channeled through the school of positivism.

According to the followers of positivism, law is the command of sovereign. Thus, anyone with law making authority is likely to have broad authority to adopt any law as he wishes. In his legal positivism view, Kelsen takes a step even further by stating that law has nothing to do whatsoever with moral. In Kelsen's words: "the concept of law has no moral connotations whatsoever. The positivist must set aside values and similar considerations during his investigation of law". ${ }^{30}$ It is not surprising therefore that the U.S. Copyright Act does not provide for the author's moral right, exactly as it has been intended by the legislators.

In Indonesia's perspective, legal positivists have attained a respected position. Even though members of society do not understand, let alone feel they need IPR, as legislators view that it is paramount for Indonesia to adopt an IPR regime, as many as 7 (seven) IPR laws were formulated and adopted. ${ }^{31}$ Although the Indonesian Constitution mandates a legal system based on brotherhood, the IPR laws enacted continue to carry their original colors of individualism. This causes no concern at all to legal positivists, and these are the exact conditions that are subsequently raising problems in the implementation of the laws concerned. Once taken out of its context, namely the society concerned, the implementation of these laws is certain to raise problems. This is where a cultural study is required with the aim of understanding IPR in the sociological context.

\section{Culture and IPR}

A study of IPR from the cultural perspective can take the approach of looking at various events related to the implementation of the laws concerned. For instance, a research conducted by the author with Indonesian as well as foreign colleagues, related to the implementation of the Copyright Law. ${ }^{32}$ The

${ }^{30}$ Kelsen in L.B. Curzon, Jurisprudence, (London: Cavendish Publishing Limited, 1993), p. 76.

31 These 7 laws include the Patent Law, the Mark Law, the Copyright Law, the Industrial Design Law, the Trade Secret Law, the Integrated Circuits Layout Law, the Plant Variety Protection Law.

${ }^{32}$ The results of research have been published in the form of Appendix to the book Hak Kekayaan Intelektual dan Pengetahuan Tradisional (Intellectual Property Rights and Traditional Knowledge) by Agus Sardjono, published by PT Alumni, Bandung, in 2010. Research was conducted in various regions all over Indonesia,including Solo, Yogyakarta, Bali, South Sulawesi, East Nusa Tenggara, West Kalimantan, North Sumatera, andWest Sumatera, from 2005 to 2007. Members of the Researchers Team included, among others: Peter Jaszi (American University), Lorraine Aragon (University of North Carolina), Jane Anderson (New York University),James Leach (Cambridge University), Joe Karaganis (Social Science 
results of this research analyze various situations related to the implementation of Copyright Law in various regions all over Indonesia. Some of the interesting points that need to be mentioned include the following, among other things: First, artistic practices are a direct continuation of long existing working methods, reflecting ideas on the techniques and themes inherited by many generations of the local communities. One of the most appropriate examples is the art of batik. The art of painting batik has been practiced in the same manner for generations, starting with the process of drawing by using "malam" (applying wax of red brownish color), cold coloring, dissolving the "malam" by boiling the colored fabric in hot water, and so on and so forth. There are indeed other techniques such as using patterns, and even printing technique in various industries. However, the latter technique cannot be referred to as the art of batik painting ("membatik").

Another rather relevant example is the production of woven fabric in Kefamenanu,Timor, and the production of songket in Kotogadang, West Sumatera. Several foreigners concerned with the preservation of local cultures are also involved in these regions, such as the Bebali Foundation (Threads of Life Gallery) based in Ubud. This foundation is managed by foreigners from the U.S. and U.K. in cooperation with local people from Bali and Yogyakarta. In Sintang, West Kalimantan, there are activities for the preservation of weaving traditions driven by Yayasan Komunikasi Budaya Seni, organized by JacMaessen. In West Sumatra, similaractivities are conducted by Erika Rianti in cooperation with Bernhard Bart from Switzerland. In South Sulawesi there are also certain activities for preserving the local culture funded by the Ford Foundation.

The above described examples indicate that in the context of local cultural expressions, local communities are extremely open, even to foreigners. They are not concerned by the prospect of their cultural products being imitated or misappropriated by foreigners. This is closely related to the subsequent finding of the research, namely that there is a tradition of the ethic of sharing. To these local communities, sharing is a noble thing to do. This tradition has been adhered to by almost all artists in the regions visited. It is this tradition of sharing that has actually made a significant contribution to the development of local cultural arts. This tradition does not only involve loyalty to the past, rather than that, it also involves the preparedness and ability to introduce innovation into tradition. In Solo, we found batik fabric produced by traditional methods, but applying combinations of patterns originating from various regions, including China. However, the batik fabric demonstrated overall strong local characteristics, namely using the sogan color with very fine and elaborate details.

Regardless of the existing diversity, all of the individuals and communities which have contributed still have their own strong commonly adhered to values. For instance in Bali, this ethics of sharing is based on the teaching on dharma, namely that every individual must contribute his or her dharma to the community. A creative artist has to dedicate his or her creation to the community. We have not been able to identify a single traditional artist whose

Research Council, USA), Agus Sardjono(Universitas Indonesia), Abdon Nababan (Aliansi Masyarakat Adat Nusantara), Ignatius Haryanto (LembagaStudiPersdan Pembangunan), Hinca Panjaitan (Indonesia Media Law and Policy Centre), danRizaldi Siagian (Etnomusicolog). 
only motivation in creative work is "money". Rather interestingly, when asked the question: "are other people allowed to use your work of art?" the answer in all instances was the same, namely that other people would be allowed to use their work of art, however by acknowledging that it was somebody else's work. ${ }^{33}$ This is the ethic of sharing which indeed focuses on the moral aspect rather than on the purely economic aspect. Indeed, there were also artists who admitted to the economic motive in using their work of art, however when asked about the reason "why?" most of them answered it was due to their awareness of the Copyright Law. This was found in the interviews conducted in Bali with contemporary painters in the above mentioned touristic areas. A different answer was obtained from painters in the Kamasan region who are creating specific Kamasan paintings.

The third interesting finding was that artists such as musicians, dancers, painters, weavers, and carvers expressed their view that their activities were a reflection of social relationships. No matter how beautiful their work of art is, they do not regard their work as something that requires protection. In the view of those involved in the system, the preservation of traditional arts is not an end, but rather an objective which reflects a greater objective, namely supporting and strengthening meaningful social life patterns. When asked about the existence of the Copyright Law that offers protection for their creativity, most of them indicated that they did not understand the concepts included in the said Law.

The fourth rather important finding of the research is related to the sustainability of traditional arts. Traditional cultural artists expressed their view that there are 3 (three) important components affecting the sustainability of the traditional arts in their community. (1) They were rather active in expressing their concern about documentation. They expressed their conviction that documentation is an effective way of preserving traditional knowledge of the past generations. There may be many different possible forms of documentation, however, all of them expressed the view that documentation is extremely important. (2) They expressed their understanding that the young generation is a problematic link in the chain in the process of transferring knowledge. Unless the appropriate steps are taken, the current young generation will become separated from their cultural roots under the strong current of foreign culture, ranging from pop culture to the content of formal education that they are exposed to. (3) Artists demonstrated an understanding that the practice of their art is likely to be significantly influenced by their own ability to satisfy the audiences which lives under new contemporary social conditions.

The above described fourth finding indicates a rather strong competition among cultures. Let us take for example the use of Western musical instruments such as the violin, trumpet, and keyboard in playing traditional music. The use of such instruments is a logical consequence of technological development which affects the quality of artistic performances, particularly in the field of music. Keyboards capable of producing sounds imitating the sound of gondang or sitar are increasingly being used in villages. ${ }^{34}$ Consequently, traditional music moral right.

${ }^{33}$ This concept is similar to the attribution right in the author's right doctrine which is part of the

${ }^{34}$ The Batak gondang music is frequently played using keyboard in Karo land or North Tapanuli. 
played by the young generation is becoming artificial, or even digital, as sounds originally produced by traditional musical instruments are now being replaced by synthesizer keyboard. According to the artists concerned, this should not be considered something that is forbidden. Traditional arts are not static, in fact, they are dynamic and are following contemporary trends.

In the context of IPR related issues, this research also came up with rather surprising results, particularly in view of cultural actors' perceptions of IPR laws, particularly the Copyright Law. According to the artists' perception, IPR laws are dealing with the new use of existing artistic sources. In their view, Copyright can even constrain the creative choices of a new author. Similarly, they consider that the application of IPR in traditional arts has the potential of hampering not only third party users, but also those involved in the traditional artistic system itself. In other words, in their view, the IPR system can potentially constrain and limit traditional arts, although it may also potentially support their activities.

Cultural actors do not need the kind of protection that is offered under the IPR system. Rather than that, they need assurance that a system can be maintained for the transmission of knowledge and practices in the everyday life of their community. This should be the main objective of any new law initiative in protecting traditional culture and arts. In general, Indonesian artists and community leaders expect a greater respect of their practices, both in their own community as well as in society at large. There is a tendency to view a failure to respect artists (when such respect is due to them) as an issue of ethical, rather than of legal dimension.

Considering the above views may prove helpful in understanding why our IPR laws enacted a long time ago are still facing obstacles in their effective implementation. For instance, the concept of exclusivity is likely to be contradictory to the idea of togetherness in the spirit of brotherhood and the ethics of sharing. An excessively economically motivated view is likely to be considered as being anti-asocial or greedy, both of which are very distant from the human qualities that uphold dharma ${ }^{35}$ and a noble character.

IPR concepts that are so closely related to the aspect of commercialization of cultural products have to face the reality that not all cultural creativity is based on purely economic motives. In the ngayah tradition in Bali, artistic practices have nothing to do with economic motives. Economic motives can only be found in the mayah activities. In other words, the failure of the IPR system at the practical level is not due to the community's reluctance to comply with IPR legal norms; rather than that, it is due to the conceptual differences that exist between the community's way of thinking and the IPR concepts.

The research team witnessed the performance of such music.

35 The dharma principle creates values or norms requiring a person to undertake deeds that are useful to other people. See again AgusSardjono, Membumikan HKI di Indonesia (Materializing IPR in Indonesia). 


\section{How to build a culture-based Indonesian IPR system?}

Admittedly, Indonesia has reached a point of no return. There is no way of turning back. Following the ratification of WTO/TRIPs Indonesia, together with other countries, has to work on the creation of free but equitable trade. Although Indonesia has ratified the WTO/TRIPs, Indonesia is still a sovereign State, both politically as well as economically and legally. Being a sovereign State, Indonesia has the freedom to independently provide for the needs of its people.

Indonesia does not have to comply with all conventions to the maximum extent stipulated in the WTO/TRIPs, as the WTO/TRIPs does not require signatory States to stipulate broader provisions than those included in this international agreement. The WTO/TRIPs requires only the minimum adjustments in line with the agreement concerned. Some countries have demonstrated an example of this. For instance, China joined the WTO only in 2005, after it had put in place all the supporting infrastructure in order to be competitive vis-a-visother countries. The U.S. does not apply the principle of first to file in its patent system. Similarly, rather than adopting a system for the protection of geographical indications in its legal system, the U.S. is applying the system of collective marks. New Zealand is applying the system for the protection of geographical indications only for wines and spirits, while for other products it has chosen to apply the fair business practices or fair competition system.

The point to be made here is that the signing of the WTO/TRIPs does not cause signatory States to lose their sovereignty, and neither does it require them to fully submit to the said agreement. Similarly, Indonesia as a sovereign and dignified country does not have to meet its obligations under the WTO/ TRIPs without reserve. Indonesia can elect a WTO/TRIPs compliance system while giving priority to its legal system based on the Constitution and its own social order. Only by doing so can Indonesia be referred to as a legally sovereign State.

\section{How should it be done?}

In answering this question, the first step is to understand the philosophical background and history of the IPR system itself. For instance, patent protection should not be considered separately from the etymological meaning of the term 'patent' itself, which means 'open' ('patent' is the antonym of 'latent' which means hidden). Patent protection has been historically granted as reward to people who were willing to teach new technologies to the people at large.

That is why one of the requirements to obtain patent protection is to prepare a description of the invention and then laying it open for public by the Government or the local Patent Office. In the historical interpretation of patent, it is indeed a reward granted to the inventor concerned. Therefore, the subsequently developed patent protection system should continue to reflect this aspect of reward being granted to the inventor. The patent protection system should not be allowed to be used simply to provide protection to certain industries in monopolizing technologies as has been the case in the course of current developments. 
Indonesia still has an opportunity to apply an appropriate patent protection system by adding the requirement that patent protection be granted in Indonesia only if the inventor concerned presents an implementation plan for the production of the product for which patent protection is being sought in Indonesia. ${ }^{36}$ In addition to the above, it should also be provided in the Patent Law that for patents protected in Indonesia there must be a transfer of technology to the industry concerned in Indonesia. Such provisions are not at all contradictory to the TRIPs system. At the same time, such a system would reflect the views prevailing in the Indonesian society upholding the ethic of sharing, which is a manifestation of the philosophy of togetherness and brotherhood.

Indeed, provisions on the requirement to implement patents in Indonesia are already articulated in the Patent Law No 14 Year 2001, namely in Article 17 paragraph (1). However, these provisions are immediately annulled by the exemption provisions of paragraph (2) of the same article. There appears to be a certain level of hesitation on the part of legislators to force patent owners to share with the Indonesian community. At the same time, it is in fact the articulation of the history andphilosophy of patent protection itself. Could this exemption be a result of influence of the industries concerned in an effort to avoid being forced to share information on their technologies?

In the context of the Copyright protection system, the history of copyright protection in Indonesia also needs to be taken into consideration. The term 'hak cipta' (author's right) is actually a correction of the copyright concept as developed in the U.K. and its colonies. While copyright places an emphasis on protection for the publishing industry, author's right corrects it by providing protection for the author. This discourse started in Europe where the legal instrument of Author's Right was first created.

Indonesia, whose legal system historically stands closer to the Netherlands than the U.K., should also be applying the concept of author's right rather than the concept of copyright. A greater level of protection should be granted to the author than the industry. It can be achieved by adopting regulations that can prevent the publishing company from taking all of the author's rights. In fact, this kind of regulation would be an articulation of the spirit of the Constitution which does not tolerate monopoly of economic resources by private parties. Licensing agreements should not be allowed to serve as an instrument for expropriating the author's rights by the reason of freedom to contract. This is the concept referred to as the 'constitutionalization of contract'. In other words, an excessively liberal contract law should be prevented by introducing the spirit of togetherness in contract law, including togetherness in the Copyright law system.

Togetherness in the copyright law system can be achieved by introducing norms that uphold author's rights, offering a broad opportunity to the author to contribute his work to the community in a way that benefits the community. Granting a greater level of copyright protection is granted to the "copyright owner" actually leads to the misappropriation of the author's rights through the institution of the freedom of contract. Such form of legal misappropriation has already been occurring in Indonesia, as the currently developed system

\footnotetext{
${ }^{36}$ See again David Vaver described above. Supra, footnote 22.
} 
inIndonesia still leaves a wide open opportunity for the abuse of IPR system for capitalistic interests.

In the plant variety protection system (PVP), farmer's rights need to be provided for as they have a great stake in obtaining high quality seeds. This system was developed in India through the Plant Breeder's Right and Farmer's Right Act $2001{ }^{37}$ Indonesia also needs to provide for PVP in a manner to ensure that the protection of a party which has developed a new plant variety does not eliminate the farmers' right to obtain high quality seeds. The protection of plant variety is not only applied to protect the seed industry, but also as a way to ensure that farmers' rights are exercised. After India has already implemented such protection, it is now Indonesia's turn to think about it and to implement it. After all, the mandate has been given under the Constitution, instructing the State to "protect the entire Indonesian native land, advance general welfare and develop the intellectual life of the nation".

\section{Conclusion}

There are of course many other things in the spirit of the Constitution and the Indonesian nation that can be explored further and applied in the IPR protection system. The discourse of IPR as part of the culture can be developed further by taking into consideration the culture living in the Indonesian society as a source of norms that can be used in formulating IPR laws and regulations. The TRIPs allows signatory states the opportunity to provide for their own IPR protection system which is suitable to the needs of their respective communities, as illustrated in the examples described above. The remaining issue is whether legislators and the law enforcement apparatus in Indonesia really care about this? Are Indonesian legislators and law enforcement apparatus still loyal to the national's fundamental philosophy or way of life view as articulated in the Constitution? Do Indonesian legislators and legal apparatus still have the spirit of freedom to fill political independence with legal and economic independence?

\section{Bibliography}

Abbott, Frederick. et al. The International Intellectual Property System: Commentary and Materials, Part One. Kluwer Law International, 1999.

Abbott, Frederick. "Protecting First World Assets in the Third World: Intellectual Property Negotiations in the GATT Multilateral Framework", Vanderbilt Journal of Transnational Law. Vol. 22, No.4, 198.

Aquinas, Thomas. The Summa Theologica: On the Essence of Law, (edited with an introduction by Anton C. Pegis. (New York: The Modern Library, no year indicated).

\footnotetext{
${ }^{37}$ India was the first country in the world to provide for plant variety and farmer's rights in the same law. Referto the abstract of AnithaRamanna, “India's Plant Variety and Farmers' Right Legislation: Potential Impact onStakeholder Access to Genetic Resources", EPTD Discussion Paper No. 96, International Food Policy ResearchInstitute, Washington: January, 2003.
} 
Aquinas, Thomas. Summa Theologica, dalam Lord Lloyd of Hampstead, Introduction to Jurisprudence, 3th ed. Praeger Publisher., 1972.

Curzon, L.B. Jurisprudence. London: Cavendish Publishing Limited, 1993.

Foster, Meika. "The Human Genome Diversity Project and the Patenting of Life: Indigenous People Cry Out", Canterbury Law Review. Vol. 7, 1999.

Kuntjaraningrat. Pengantar Antropologi. Jakarta: AksaraBaru, Cet.V, no year indicated.

Ramanna, Anitha. “India's Plant Variety and Farmers' Right Legislation: Potential Impact on Stakeholder Access to Genetic Resources", EPTD Discussion Paper No. 96, International Food Policy Research Institute. Washington: January,2003.

Ritchie, Mark. et al. "Intellectual Property Rights and Biodiversity: The Industrialization of Natural Resources and Traditional Knowledge", St.Johns Journal of Legal Commentary, Vol. 11, 1996.

Sardjono, Agus. Hak Kekayaan Intelektual dan Pengetahuan Tradisional. Bandung:Alumni, 2010.

Sardjono, Agus. Membumikan HKI di Indonesia. Bandung: NuansaAulia, 2009.

Sumaryono, E. Etika Hukum: Relevansi Hukum Kodrat Thomas Aquinas. Yogyakarta: Kanisius,2002.

Suwarsono \& Alvin Y. So, Social Change and Development. Jakarta: LP3ES, 1994. Vaver, David. "Intellectual Property Today: Of Myths and Paradoxes", Canadian Bar Review, Vol. 69, 1990. 